\title{
Cechy drzew i drzewostanu a występowanie dzięcioła średniego Leiopicus medius - wskazówki dla gospodarki leśnej na przykładzie Puszczy Niepołomickiej
}

\author{
PrzemysŁaw Kurek, Łukasz Piechnik, Mateusz Ledwoń, \\ Grażyna SzareK-Łukaszewska, PaweŁ Kapusta i Jan HoleKsa
}

\begin{abstract}
Kurek, P., Piechnik, Ł., Ledwoń, M., Szarek-Łukaszewska, G., Kapusta, P. and Holeksa, J. 2020. Trees and forest structure characteristics and the occurrence of Middle Spotted Woodpecker Leiopicus medius - implications for forest management. Fragmenta Floristica et Geobotanica Polonica 27(1): 45-54. Kraków. e-ISSN 2449-8890, ISSN 1640-629X.

Abstract: The Middle Spotted Woodpecker (Leiopicus medius) is considered a habitat specialist whose occurrence strongly depends on the presence of trees with cracked bark. This is related to the way the bird feeds - it collects arthropods from cracks in bark. Oaks are conspicuous for their deeply cracked bark. The aim of this study was to determine the relationship between the characteristics of trees and tree stands of different species composition (suboptimal coniferous and optimal oak-hornbeam forests) and the presence/breeding of the Middle Spotted Woodpecker. The following stand characteristics were taken into account: total number of dead branches, number of sporophores on stems, maximum diameter at breast height and basal area of oak, and basal area of dead trees. The higher oak stand age was the only trait close to statistical significance in breeding sites. Analysis of the preferences of the Middle Spotted Woodpecker at breeding sites suggests that this species requires an oak stand exhibiting diverse structure for the whole set of features. Stand age seems to be one of the most important features that the Middle Spotted Woodpecker uses when choosing its territory.
\end{abstract}

KEY WORDS: Leiopicus medius, preferences, protection, stand characteristics

P. Kurek (autor korespondencyjny), J. Holeksa, Zakład Ekologii Roślin i Ochrony Środowiska, Wydziat Biologii, Uniwersytet im. Adama Mickiewicza w Poznaniu, ul. Uniwersytetu Poznańskiego 6, 61-614 Poznań,Polska; e-mail: przkur1@amu.edu.pl

Ł. Piechnik, G. Szarek-Łukaszewska, P. Kapusta, Instytut Botaniki im. W. Szafera Polskiej Akademii Nauk, ul. Lubicz 46, 31-512 Kraków, Polska

M. Ledwoń, Instytut Systematyki i Ewolucji Zwierzqt Polskiej Akademii Nauk, ul. Stawkowska 17, 31-016 Kraków, Polska

\section{WSTĘP}

Dzięcioł średni Leiopicus medius (L.) jest nielicznym lub lokalnie średnio licznym ptakiem lęgowym niżu (TomiaŁojć \& Stawarczyk 2003; Chodkiewicz i in. 2015). Zasiedla głównie Europę Środkową, sięgając swym przerywanym zasięgiem na zachód, aż po Francję. Występuje także w Turcji i na Kaukazie. W Europie jego zasięg pokrywa się głównie z obecnością dębów Quercus spp., dlatego uznany został za gatunek ptaka o wąskiej specjalizacji 
siedliskowej (habitat specialist; PetTersson 1983; Pasinelli 2000a). Dzięcioł średni może być mylony z dzięciołem dużym Dendrocopos major i dzięciołem białoszyim Dendrocopos syriacus. Spośród pozostałych, rodzimych gatunków z rzędu Piciformes, dzięcioł ten charakteryzuje się raczej małymi rozmiarami. Samce cechują się nieco większą masą ciała i długością dzioba niż samice (PASINELLI 2000b). Charakterystyczną cechą budowy tego ptaka jest stosunkowo słaby dziób, co w połączeniu z małą masą ciała czyni go dzięciołem delikatnej budowy (KosiŃsKi \& Ksit 2007; HeBDA i in. 2016). Cechy te wpływają bezpośrednio na jego sposób żerowania, który polega na zbieraniu stawonogów zasiedlających pęknięcia i różnego rodzaju szczeliny w korze drzew.

Występowanie dzięcioła średniego jest uzależnione przede wszystkim od obecności drzew z silnie spękaną korą (KosiŃSKI 2006). Taką korę, nawet już w młodym wieku, posiadają dęby, dlatego są miejscem żerowania preferowanym przez tego ptaka. Badania wykazały, że dęby nie posiadają specyficznej fauny stawonogów, z którą mógłby być związany dzięcioł średni, gdyż owady stanowiące jego pokarm występują również na innych gatunkach drzew (PASINELli \& Hegelbach 1997). Dzięcioł średni nie jest więc związany z konkretnymi gatunkami monofagów dębu, lecz z liczną fauną stawonogów zasiedlającą specyficzną, chropowatą i szczelinowatą korę (SoutHwOOD 1961; NiCOLAI 1986). Klimat, a zwłaszcza występowanie ostrych zim, jest kolejnym czynnikiem, który silnie wpływa na rozmieszczenie dzięcioła średniego w Europie; jego występowanie jest ograniczone na przykład w porównaniu ze znacznie dalej na północ docierającym dzięciołem dużym (KosIŃSKI \& KsIT 2006). Oblodzenie oraz śnieg, zalegające na konarach i pniach, uniemożliwiają dostęp do pokarmu, co stanowi główny czynnik regulujący liczebność na północnym skraju zasięgu tego ptaka (PASINELL 2000a).

Celem niniejszej pracy jest: 1) poznanie zależności między cechami drzew i drzewostanów, a obecnością/lęgowością dzięcioła średniego oraz 2) określenie wytycznych dla gospodarki leśnej, mających na celu pogodzenie ochrony gatunku z gospodarowaniem w lasach.

\section{TEREN BADAŃ}

Badania prowadzono w Puszczy Niepołomickiej $\left(50^{\circ} 02^{\prime} \mathrm{N}, 20^{\circ} 33^{\prime} \mathrm{E}\right)$, kompleksie leśnym o powierzchni ok. 11000 ha, znajdującym się w zachodniej części Kotliny Sandomierskiej, makroregionu będącego częścią podprowincji Północne Podkarpacie (KONDRACKI 2000). Płaskie dno Kotliny podnosi się od rzeki Wisły ku południowi. Cały teren tworzy rozległą, piaszczystą równinę starszego stożka napływowego rzeki Raby. Nie ma tu znaczących wzniesień, przeciętna wysokość terenu wynosi około 200 m n.p.m. (BzowsKi 1973). W wyniku prowadzonych w przeszłości intensywnych prac odwadniających (GŁowACIŃSKI \& KAŹMIERCZAKOWA 1978) nastąiło na tym terenie obniżenie poziomu wody gruntowej o około 30-50 cm (BzowsKi 1978). Lokalny klimat wykazuje wpływy dużej wilgotności podłoża oraz rozległych obszarów leśnych. Przejawia się to m.in. nieco niższą, niż na terenach sąsiadujących z Puszczą Niepołomicką, średnią temperaturą roku oraz wysoką średnią wilgotnością powietrza (KLEIN 1978).

W Puszczy Niepołomickiej powierzchniowo dominują dwa zbiorowiska roślinne: kontynentalny bór mieszany Pino-Quercetum (74\%) z dużym udziałem sosny zwyczajnej Pinus 
sylvestris i domieszką dębów Quercus spp. oraz subkontynentalny grąd Tilio-Carpinetum (22\%) z dominacją dębu szypułkowego Quercus robur w drzewostanie (GRUSZCZYK 1981; MYcZKowski 1981). Większość powierzchni (98,5\%) Puszczy stanowi las gospodarczy, w którym dominują rębnie zupełne gniazdowe z odnowieniem sztucznym (PUL 2011).

W ramach sieci Natura 2000 na terenie Puszczy Niepołomickiej ustanowiono Obszar Specjalnej Ochrony Ptaków Puszcza Niepołomicka (PLB120002) ze względu na występowanie muchołówki białoszyjej Ficedula albicollis, puszczyka uralskiego Strix uralensis, dzięcioła czarnego Dryocopus martius oraz dzięcioła średniego Leiopicus medius. Wyznaczono również trzy Specjalne Obszary Ochrony Siedlisk: Torfowisko Wielkie Błoto (PLH120080), Koło Grobli (PLH120008) oraz Lipówka (PLH120010).

\section{Metody}

\section{Zbiór danych}

Na podstawie materiałów kartograficznych i zdjęć lotniczych Puszczy Niepołomickiej oraz wyników wizji terenowej wytypowano 100 powierzchni badawczych $(51 \mathrm{w}$ drzewostanach liściastych, roboczo nazywanych tu grądami) i $49 \mathrm{w}$ drzewostanach sosnowych z niewielką domieszką dębu (roboczo nazywanych tu borami mieszanymi). Powierzchnie badawcze o wielkości 10 ha (kwadrat o boku $316 \mathrm{~m}$ ), porośnięte były drzewostanem w wieku powyżej 60 lat. Na powierzchniach badawczych wykonano pomiary grubości wszystkich drzew żywych i martwych o grubości powyżej $10 \mathrm{~cm}$ w pierśnicy. Odnotowywano gatunek drzewa oraz, posługując się lornetką, występowanie owocników hub i martwych konarów. Wiek drzewostanu określono na podstawie danych Nadleśnictwa Niepołomice.

Wiosną 2016 r. na wszystkich powierzchniach badawczych przeprowadzono dwie kontrole ornitologiczne. Pierwsza kontrola miała miejsce w okresie od 21 do 31 marca, a druga w okresie od 9 do 18 kwietnia. Kontrole wykonało dziewięciu ornitologów mających doświadczenie w prowadzeniu badań na terenach leśnych. Podczas każdej kontroli obserwacje były prowadzone na danej powierzchni tylko raz, w godzinach porannych (do 11:00).

Kontrola polegała na odtwarzaniu głosu dzięcioła średniego w czterech punktach, rozmieszczonych równomiernie na powierzchni badawczej (co 100-150 m). Głos odtwarzany był przez 30 sekund, po czym następował nasłuch trwający 120 sekund. W razie uzyskania reakcji głosowej lub wizualnego stwierdzenia osobnika (osobników) przerywano stymulację. Czas przeznaczony na wykonanie jednej kontroli na jednej powierzchni ustalono na 80 minut. Wynikiem kontroli każdej powierzchni było stwierdzenie obecności badanego gatunku lub jej brak (presence/absence). Każdy ornitolog miał do dyspozycji urządzenie GPS z wgranymi granicami powierzchni badawczej, trasą przejścia i czterema punktami wabienia. Wyniki były notowane na kartach terenowych. Kontrole odbywały się jedynie w dni bezdeszczowe i bez silnego wiatru.

Wyróżniono trzy kategorie lęgowości gatunku w zależności od liczby stwierdzeń: kategoria 0 - nie wykazano obecności ptaków podczas żadnej z dwóch przeprowadzonych kontroli; 1 - ptak prawdopodobnie lęgowy, stwierdzono obecność gatunku podczas jednej z dwóch przeprowadzonych kontroli; 2 - ptak lęgowy, stwierdzono obecność gatunku podczas obu kontroli terenowych.

\section{Analiza danych}

Uzyskane dane analizowano oddzielnie dla borów mieszanych oraz dla grądów. W borach mieszanych, z powodu nierównej liczby stwierdzeń w kategoriach 0,1 i 2, porównywano cechy drzewostanu na powierzchniach z dzięciołem (połączono kategorie 1 i 2) z powierzchniami, na których dzięcioła nie stwierdzono. Natomiast w grądach, gdzie nie było powierzchni bez dzięcioła (kategoria 0), porównywano cechy drzewostanu między stanowiskami prawdopodobnie lęgowymi (1) i lęgowymi (2). Zmiennymi 
wyjaśniającymi były: sumaryczna liczba martwych konarów, liczba drzew z hubami, pierśnicowe pole przekroju martwych drzew, maksymalna pierśnica i pierśnicowe pole przekroju dębu oraz wiek drzewostanu odczytany z opisu taksacyjnego drzewostanów Nadleśnictwa Niepołomice. Częstość występowania gatunku obliczono w oparciu o liczbę stwierdzeń w kategorii 2 (lęgowy) oddzielnie w obydwu typach lasu.

Przed analizą danych zmienne ciągłe, charakteryzujące się skośnymi rozkładami, transformowano przy pomocy funkcji logarytmicznej lub wykładniczej, aby uzyskać rozkład normalny lub zbliżony do normalnego. Istotność różnic pomiędzy grupami powierzchni (np. powierzchnie lęgowe vs. prawdopodobnie lęgowe) badano za pomocą jednoczynnikowej analizy wariancji (ANOVA). Różnice w proporcji stwierdzeń ptaków lęgowych (kategoria 2) między borami mieszanymi i grądami (tabela liczności $2 \times 2$ ) analizowano przy pomocy testu chi-kwadrat $\left(\chi^{2}\right)$. W celu określenia zależności między wiekiem drzewostanu a występowaniem dzięcioła średniego (zmienna binarna 0-1, przy czy wartość 1 przypisano powierzchniom z kategorią lęgowości 2 - lęgowy) wykorzystano regresję logistyczną. Wszystkie analizy wykonano w środowisku R w wersji 3.5.3 (R CORE TEAm 2019) z wykorzystaniem pakietów: 'lme4' (BATES i in. 2015), 'ggplot2' (WicKHAM 2016), 'ggthemes' (ARnOld i in. 2019), 'car' (Fox \& WeISBERG 2019) oraz 'carData' (Fox i in. 2019).

\section{WYNIKI}

W grądach częstość występowania lęgowego dzięcioła średniego wynosiła 73\% (na 37 powierzchniach), a prawdopodobnie lęgowego 27\% (na 14 powierzchniach). W borach mieszanych częstość występowania lęgowego dzięcioła średniego wynosiła 6\% (3 powierzchnie), a częstość występowania prawdopodobnie lęgowego wynosiła 14\% (7 powierzchni). Dzięcioła średniego nie stwierdzono aż na $80 \%$ powierzchni (39 powierzchni) w borach mieszanych. Różnice w lęgowości ptaków między grądami i borami mieszanymi były istotne $\left(\chi^{2}=21,1, d f=1, p<0,0001\right)$.

Zarówno $\mathrm{w}$ grądach jak i w borach mieszanych nie wykazano istotnych statystycznie różnic między kategoriami lęgowości pod względem: sumarycznej liczby martwych konarów, liczby drzew z hubami, pierśnicowego pola przekroju martwych drzew, maksymalnej pierśnicy oraz pierśnicowego pola przekroju dębów. W grądach stwierdzono natomiast wyższy wiek drzewostanu na stanowiskach lęgowych niż na stanowiskach prawdopodobnie lęgowych (Ryc. 1). Różnice te były bliskie statystycznej istotności (ANOVA, $F=3,49$, $p=0,068)$. Analiza logistyczna wykazała, że w drzewostanach grądowych w wieku około 70 lat prawdopodobieństwo lęgowego występowania dzięcioła średniego wynosi 50\%, w wieku 100 lat - 70\%, a w wieku 150 lat - niemal 90\% (Ryc. 2).

\section{DYSKUSJA}

Puszcza Niepołomicka jest jedną z ważniejszych ostoi dzięcioła średniego w Polsce (WILK $\mathrm{i}$ in. 2013). Grądy stanowią optymalne środowisko występowania dzięcioła średniego, dlatego analizę czynników sprzyjających trwaniu populacji tego gatunku odnosimy do danych otrzymanych z grądów. Niniejsze badania pokazały, że na powierzchniach grądowych z ponad 60-letnim drzewostanem częstość występowania lęgowego dzięcioła średniego wynosi $73 \%$. We wcześniejszych badaniach prowadzonych na tym samym obszarze wykazano zagęszczenie dzięcioła średniego na poziomie $0,7-1,0$ pary na 10 ha (WILK i in. 2013). 

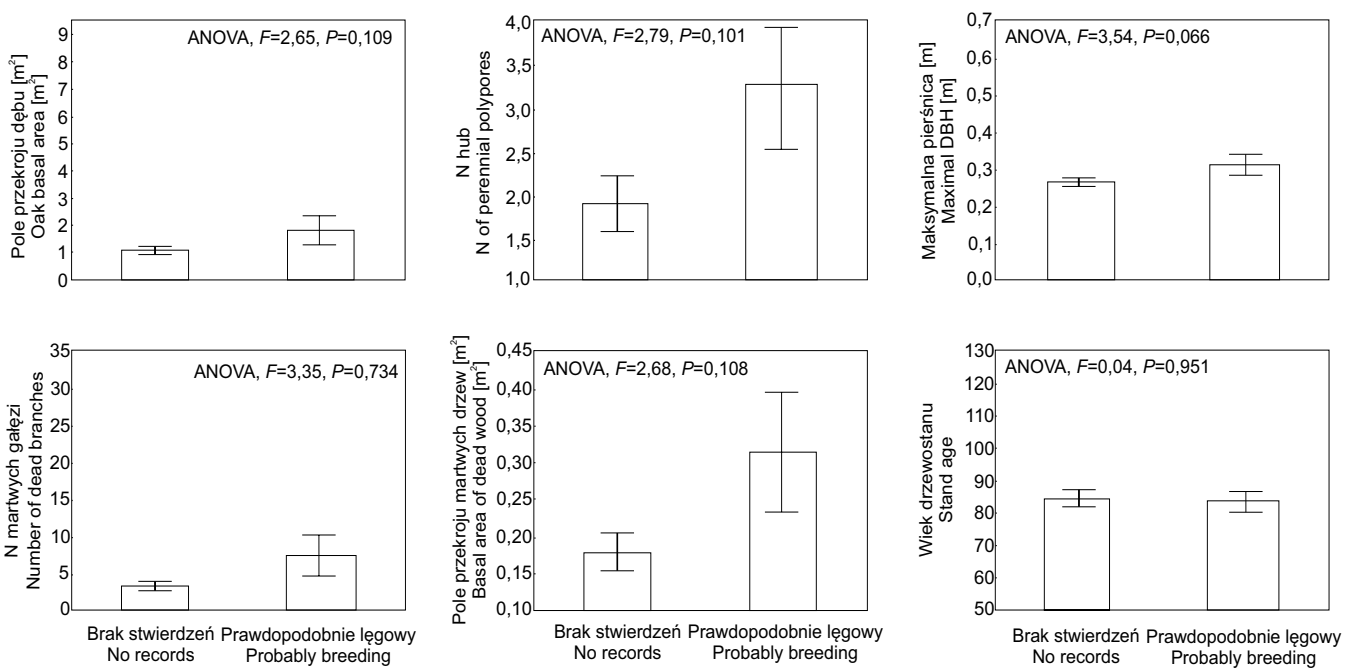

GRADY - DECIDUOUS FORESTS
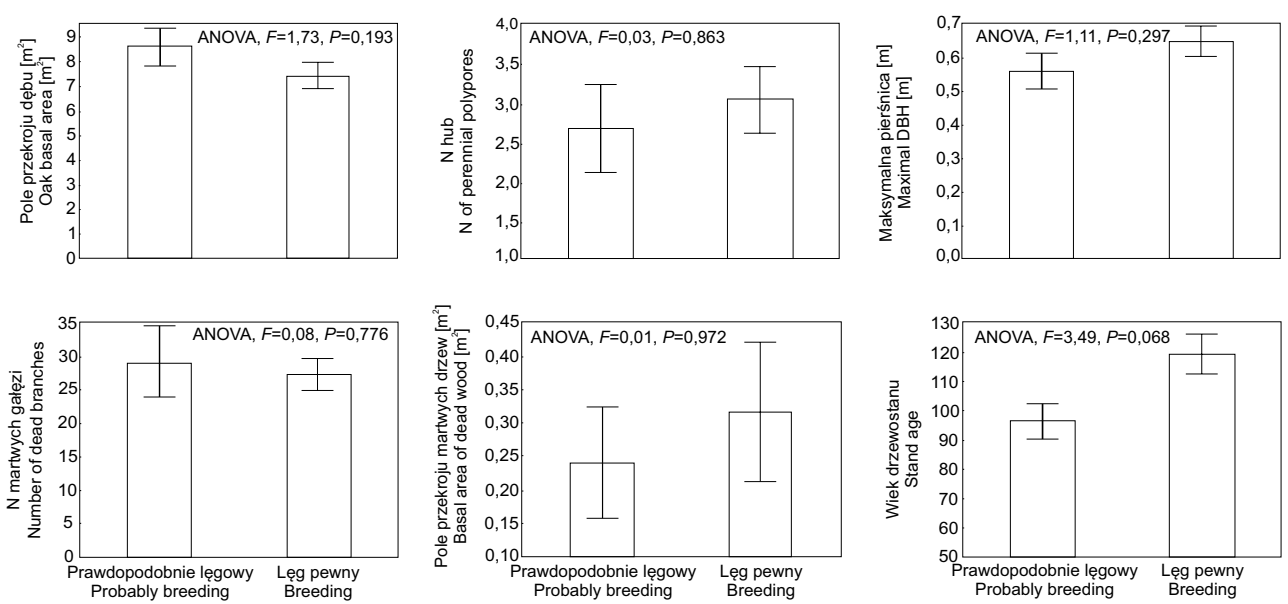

Ryc. 1. Cechy drzewostanu w borach mieszanych i grądach (średnia \pm błąd standardowy), w którym dzięcioł średni: 0 - nie był stwierdzony, 1 - był prawdopodobnie lęgowy (stwierdzony tylko podczas jednej kontroli), 2 - był lęgowy (stwierdzony podczas obu kontroli). W przypadku borów mieszanych analizowano kategorie 0 oraz 1 , natomiast w przypadku grądów analizowano kategorie 1 oraz 2, ponieważ nie wykazano kategorii 0

Fig. 1. Trees and forest structure characteristics in coniferous and deciduous forests (mean \pm standard error) where Middle Spotted Woodpecker occurred: 0 - no occurrence, 1 - probably breeding (reported in single control), 2 - breeding (reported in both censuses). In case of coniferous forests only categories 0 and 1 were analysed, in case of deciduous forests only categories 1 and 2 were analysed (category 0 was not reported)

Wyniki te zawierają się wśród średnich wartości przedziału dla naszego kraju, które wynoszą od 0,1 do 2,5 par na 10 ha (Tomialojć \& STAWARCZYK 2003). Otrzymane wyniki potwierdziły równocześnie, że lęgowy dzięcioł średni jest stwierdzany bardzo rzadko w borach mieszanych - zaledwie na 6\% powierzchni (HEBDA i in. 2016). 


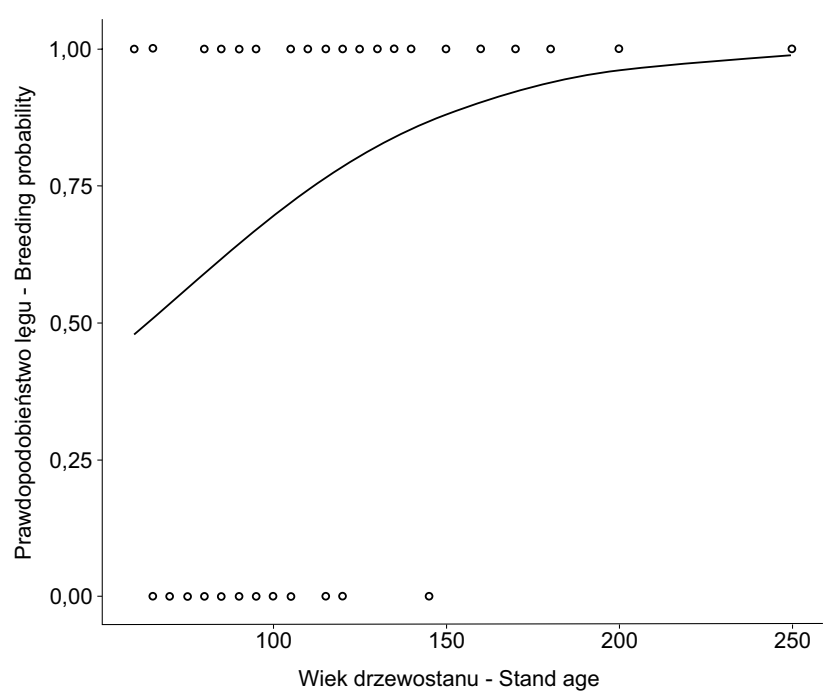

Ryc. 2. Prawdopodobieństwo lęgowości dzięcioła średniego w zależności od wieku drzewostanu dębowego na siedlisku grądu

Fig. 2. The probability of Medium spotted woodpecker occurrence depending on oak forest stand age

Dzięcioł średni wymaga drzewostanu dębowego, charakteryzującego się zróżnicowaną strukturą (STACHURA-SKIERCZYŃSKA \& KosiŃSKI 2016). Dlatego analizowanie poszczególnych cech drzewostanu oddzielnie niejednokrotnie nie pozwala na stwierdzenie istotnych zależności pomiędzy ich obecnością, a występowaniem lęgów dzięcioła średniego. Wiek drzewostanu wydaje się być jednym z ważniejszych kryteriów wyboru miejsca lęgowego u tego gatunku (RoBles i in. 2007). Stwierdzono, że stare, a tym samym najczęściej duże drzewa, są pożądanym elementem środowiska dzięciołów (CiACH 2011). Liczba terytoriów lęgowych dzięcioła średniego zależy pozytywnie od liczby starych drzew oraz udziału starych drzewostanów (STACHURA-SKIERCZYŃSKA \& KosińSKi 2016). Prawdopodobieństwo wystąpienia dzięcioła średniego w lesie wyraźnie wzrasta w drzewostanach, które przekroczyły wiek 80 lat (KosińSKi 2006). Drzewostany powyżej 120 lat są wyraźnie preferowane (KOSIŃSKI \& WINIECKI 2005).

Wiek drzewostanu jest tak ważną cechą, ponieważ wraz z wiekiem drzewostanu rośnie bogactwo ważnych dla dzięcioła średniego mikrosiedlisk (spękania kory, martwice, próchnowiska, huby, suche konary, itp.), a tym samym poprawia się efektywność żerowania i zwiększa się możliwość odbycia lęgów. Przykładowo, w Lesie Odrzańskim prawie 90\% dziupli tego gatunku było zlokalizowanych w obrębie martwic i blizn (JERZAK i in. 2011). Prawidłowość tę stwierdzili również inni autorzy (PetTersson 1983; PAsinelli 2007). Dzięcioł średni bardzo często zakłada dziuple u podstawy gałęzi w żywych dębach i jesionach wyniosłych Fraxinus excelsior (Kosı́́sKI i in. 2006). W Puszczy Białowieskiej często wybierał zamierające drzewa (HeBDA $i$ in. 2016). Jednak w lasach gospodarczych eliminacja drzew wykazujących wady techniczne drewna podczas trzebieży i cięć przygodnych powoduje, że ilość mikrosiedlisk ważnych z punktu widzenia ekologii żerowania i gniazdowania dzięcioła średniego jest bardzo mała. Badania prowadzone w lasach Europy potwierdzają, że mikrosiedliska związane 
z drzewami starymi i zamierającymi są mniej liczne w lasach intensywnie zagospodarowanych (Müller \& BütLer 2010; PAWLACZYK 2014; ANDERSSON i in. 2017).

Nasze wyniki potwierdzają znaczenie wieku drzewostanu dla występowania dzięcioła średniego. Stwierdzono, że im wyższy był wiek drzewostanu grądowego, tym większa była szansa, że dzięcioł średni będzie miał status „lęgowy”, a nie „prawdopodobnie lęgowy” (Ryc. 2). W drzewostanach, które osiągnęły 140-150 lat, prawdopodobieństwo lęgowego wystąpienia dzięcioła średniego mieści się między 80 a 90\%. Zachowanie populacji tego gatunku zależy zatem od obecności starych drzewostanów grądowych z wysokim udziałem dębu. Na podstawie uzyskanych wyników można uznać, że po osiągnięciu 140 lat drzewostany takie reprezentują optymalne warunki pod względem preferencji lęgowych dzięcioła średniego. Zatem, należy czynić starania, aby udział powierzchniowy takich starych drzewostanów był możliwie największy. W Planie Urządzenia Lasu dla Nadleśnictwa Niepołomice (PUL 2011) przyjęto dla drzewostanów dębowych wiek rębności wynoszący 180 lat. Oznacza to, że drzewostany dębowe w Puszczy Niepołomickiej przez 40 lat zapewniają optymalne warunki dla dzięcioła. Okres ten stanowi nieco ponad $20 \%$ całego cyklu rozwojowego drzewostanu, z czego można wnioskować, że udział powierzchniowy 140-180 letnich drzewostanów będzie kształtować się na podobnym poziomie. Co więcej, 40-letni okres panowania optymalnych warunków w tym samym drzewostanie powinien być korzystny dla funkcjonowania populacji dzięcioła średniego. Należy zatem uznać, że przyjęty w Puszczy Niepołomickiej wiek rębności dla dębu, wynoszący 180 lat, spełnia potrzebne warunki dla ochrony dzięcioła średniego. Poza przestrzeganiem przyjętego wieku rębności uzasadnione jest także zalecenie, aby ograniczyć do niezbędnego minimum cięcia przygodne, w trakcie których miałyby być usuwane z drzewostanu stare zamierające dęby.

Ze względu na szczególne zachowania żerowe dzięcioła średniego (zbieranie bezkręgowców ze szczelin w korze) czasem neguje się znaczenie martwego drewna dla tego gatunku. Tymczasem okazuje się, że dzięcioł ten wykorzystuje martwe drzewa jako miejsce żerowania szczególnie w okresie zimy (PETTERSSON 1983). Dodatkowo, PASINELLI (2007) wykazał, że martwe drzewa stanowią bardzo ważną bazę do wykuwania dziupli i są preferowane przez ten gatunek. Obserwacje te potwierdza HEBDA i in. (2016) z Puszczy Białowieskiej. W lasach dębowych w Szwajcarii zaobserwowano wyższą liczebność tego gatunku, przy zasobności stojących martwych drzew równej $9,3 \mathrm{~m}^{3} /$ ha (SPÜHLER i in. 2015). Tymczasem badania przeprowadzone na terenie Puszczy Niepołomickiej wskazują na niską przeciętną zasobność martwego drewna w postaci stojących pni, wynoszącą $3,4 \mathrm{~m}^{3} /$ ha (KAPUSTA $\mathrm{i}$ in. 2020). Jest to znacznie mniej niż wynoszą oczekiwania wobec lasów mieszanych, mających kluczowe znaczenie dla zachowania różnorodności biologicznej (MüLLER \& BüTLER 2010). Ilość martwych drzew w grądach Puszczy Niepołomickiej jest ponadto znacznie niższa od rekomendowanej w Planie Zadań Ochronnych, według którego ta ilość powinna kształtować się na poziomie $20 \mathrm{~m}^{3}$ /ha (ZARZĄDZENIE 2014). Oznacza to, że pod tym względem siedliska dzięcioła średniego nie są właściwie chronione i zmian wymaga dotychczasowy sposób gospodarowania w lasach Puszczy Niepołomickiej objętych ochroną w ramach obszaru Natura 2000 (PERZANOwSKA \& GRZEGORCZYK 2009). W celu zwiększenia ilości martwych drzew, rekomendowanej w Planie Zadań Ochronnych, zaleca się pozostawianie większej liczby martwych drzew stojących, zwłaszcza podczas wykonywania trzebieży 
późnych, cięć przygodnych i rębnych. Jednocześnie należy podkreślić, że znaczenie rezerwatów przyrody oraz obszarów, na których nie prowadzi się pozyskania drewna (tzw. powierzchni referencyjnych), jest nie do przecenienia dla zachowania optymalnych siedlisk dzięcioła średniego na badanym obszarze.

Podziękowania. Badania były finansowane z środków Państwowego Gospodarstwa Leśnego Lasy Państwowe w ramach grantu pt. Kształtowanie się zasobów martwego drewna $w$ siedliskach przyrodniczych $w$ warunkach prowadzenia zrównoważonej gospodarki leśnej (Nr OR.271.3.9.215) oraz środków statutowych Instytutu Botaniki im. W. Szafera Polskiej Akademii Nauk. Autorzy dziękują również Nadleśnictwu Niepołomice za umożliwienie prowadzenia badań na terenie Puszczy Niepołomickiej oraz wszystkim osobom, które brały udział w pracach terenowych.

\section{LITERATURA}

Andersson J., Gómez E. D., Michon S. \& Roberge J. M. 2017. Tree cavity densities and characteristics in managed and unmanaged Swedish boreal forest. - Scandinavian Journal of Forest Research 33: 233-244.

Arnold J. B., Daroczi G., Weitzner B., Kunst J., Auguie B., Rudis B., Wickham H., Talbot J. \& LonDON J. 2019. ggthemes: Extra Themes, Scales and Geoms for 'ggplot2'. https://cran.r-project.org/web/ packages/ggthemes/index.html

Bates D., Maechler M., Bolker B. \& Walker S. 2015. Fitting linear mixed-effects models using lme4. - Journal of Statistical Software 67(1): 1-48.

Bzowski M. 1973. Rzeźba i stosunki wodne dna doliny Wisły w rejonie północnej części Puszczy Niepołomickiej. - Studia Naturae A 7: 7-37.

Bzowski M. 1978. Stosunki wodne rezerwatu leśnego Lipówka w Puszczy Niepołomickiej. - Studia Naturae A 17: 55-65.

Chodkiewicz T., Kuczyński L., Sikora A., Chylarecki P., Neubauer G., Ławicki Ł. \& Stawarczyk T. 2015. Ocena liczebności populacji ptaków lęgowych w Polsce w latach 2008-2012. - Ornis Polonica 56: 149-189.

Ciach M. 2011. Martwe i zamierające drzewa w ekosystemie leśnym - ilość, jakość i zróżnicowanie. - Studia i Materiały Centrum Edukacji Przyrodniczo-Leśnej w Rogowie 13(2): 186-199.

Fox J. \& WeIsberg S. 2019. An R companion to applied regression. Third edition. Sage, Thousand Oaks, CA. https://socialsciences.mcmaster.ca/jfox/Books/Companion/.

Fox J., Weisberg S. \& Price B. 2019. carData: companion to applied regression data sets. R package version 3.0-3. https://CRAN.R-project.org/package=carData

GŁOWACIŃSKi Z. \& KAŹMIERCZAKOWA R. 1978. Ogólna charakterystyka przyrodnicza rezerwatu leśnego Lipówka w Puszczy Niepołomickiej. - Studia Naturae A 17: 9-36.

GruszczyK A. 1981. Siedliskowe typy lasu Puszczy Niepołomickiej. - Studia Ośrodka Dokumentacji Fizjograficznej 9: 205-216.

Hebda G., WesoŁowski T. \& Rowiński P. 2016. Nest sites of Middle Spotted Woodpeckers Leiopicus medius in a primeval forest. - Ardea 104: 119-128.

Jerzak L., Ciebiera O., Michalski Ł. \& ReKTOR R. 2011. Liczebność, zagęszczenie i miejsca lęgowe dzięcioła średniego Dendrocopos medius w Zielonogórskim Lesie Odrzańskim. - Ptaki Śląska 18: 19-25.

Kapusta P., Kurek P., Piechnik Ł., Szarek-Łukaszewska G., Zielonka T., Żywiec M. \& Holeksa J. 2020. Natural and human-related determinants of dead wood quantity and quality in a managed European lowland temperate forest. - Forest Ecology and Management 459: 117845. 
KLEIN J. 1978. Fitoklimat leśnego rezerwatu Lipówka w Puszczy Niepołomickiej. - Studia Naturae A 17: 37-54.

KONDRACKI J. 2000. Geografia regionalna Polski. s. 305-307. Wydawnictwo Naukowe PWN, Warszawa.

KosIŃSKI Z. 2006. Factors affecting the occurrence of middle spotted and great spotted woodpeckers in deciduous forests - a case study from Poland. - Annales Zoologici Fennici 43: 198-210.

Kosiński Z. \& KsIT P. 2006. Comparative reproductive biology of Middle Spotted Woodpeckers Dendrocopos medius and Great Spotted Woodpeckers D. major in a riverine forest. - Bird Study 53: 237-246.

Kosiński Z. \& KsIT P. 2007. Nest holes of Great Spotted Woodpeckers Dendrocopos major and Middle Spotted Woodpeckers D. medius: Do they really differ in size? - Acta Ornithologica 42: 45-52.

KosIŃSKi Z. \& WINIECKI A. 2005. Factors affecting the density of the middle spotted woodpecker Dendrocopos medius: a macrohabitat approach. - Journal of Ornithology 146: 263-270.

KosińSKi Z., Ksit P. \& Winiecki A. 2006. Nest sites of Great Spotted Woodpeckers Dendrocopos major and Middle Spotted Woodpeckers Dendrocopos medius in near-natural and managed riverine forests. - Acta Ornithologica 41: 21-32.

MÜLLER J. \& BÜTLER R. 2010. A review of habitat thresholds for dead wood: a baseline for management recommendations in European forests. - European Journal of Forest Research 129: 981-992.

Myczkowski S. 1981. Lasy grądowe Puszczy Niepołomickiej. - Studia Ośrodka Dokumentacji Fizjograficznej 9: 117-130.

NiCOLAI V. 1986. The bark of trees: thermal properties, microclimate and fauna. - Oecologia 69: 148-160.

PASINELLI G. 2000a. Oaks Quercus spp. and only oaks? Relations between habitat structure and home range size of the middle spotted woodpecker Dendrocopos medius. - Biological Conservation 93: 227-235.

PASINELli G. 2000b. Sexual dimorphism and foraging niche partitioning in the Middle Spotted Woodpecker Dendrocopos medius. - Ibis 142: 635-644.

PASINELli G. 2007. Nest site selection in middle and great spotted woodpeckers Dendrocopos medius and D. major: implications for forest management and conservation. - Biodiversity and Conservation 16: 1283-1298.

Pasinelli G. \& Hegelbach J. 1997. Characteristics of trees preferred by foraging Middle Spotted Woodpecker Dendrocopos medius in northern Switzerland. - Ardea 85: 203-209.

PAWLACZYK P. 2014. Martwe drewno i mikrosiedliska nadrzewne w leśnych siedliskach przyrodniczych Puszczy Drawskiej. - Studia i Materiały Centrum Edukacji Przyrodniczo-Leśnej w Rogowie 16(41): 86-97.

Perzanowska J. \& GRZEgorczyK M. 2009. Obszary Natura 2000 w Małopolsce. s. 311. Instytut Ochrony Przyrody PAN, Kraków.

PetTERSSON B. 1983. Foraging behaviour of the middle spotted woodpecker Dendrocopos medius in Sweden. - Holarctic Ecology 6: 263-269.

PUL. 2011. Plan Urządzenia Lasu Nadleśnictwa Niepołomice na okres gospodarczy od 1 stycznia 2012 do 31 grudnia 2021. Biuro Urządzania Lasu i Geodezji Leśnej, Oddział w Krakowie.

Robles H., Ciudad C., Vera R., Olea P. P., Purroy F. J. \& Matthysen E. 2007. Sylvopastoral management and conservation of the middle spotted woodpecker at the south-western edge of its distribution range. - Forest Ecology and Management 242: 343-352.

Southwood T. R. E. 1961. The number of species of insects associated with various trees. - Journal of Animal Ecology 30: 1-8.

SpüHLER L., KRÜsI B. O. \& PAsinelli G. 2015. Do Oaks Quercus spp., dead wood and fruiting Common Ivy Hedera helix affect habitat selection of the Middle Spotted Woodpecker Dendrocopos medius? - Bird Study 62(1): 115-119. 
StACHURA-SKIERCZYŃSKA K. \& KosIŃSKI Z. 2016. Do factors describing forest naturalness predict the occurrence and abundance of middle spotted woodpecker in different forest landscapes? - Ecological Indicators 60: 832-844.

Tomiąojć L. \& StawarczyK T. 2003. Awifauna Polski. Rozmieszczenie, liczebność i zmiany. s. 518-520. PTPP proNatura, Wrocław.

Wicкнам H. 2016. ggplot2: Elegant Graphics for Data Analysis. s. viii + 213. Springer-Verlag, New York.

Wilk T., Bobrek R., Paciora K. \& Springer S. 2013. Wybrane ptaki lęgowe Puszczy Niepołomickiej w latach 2004-2011. - Ornis Polonica 54: 50-67.

ZARZĄDZENIE 2014. Zarządzenie regionalnego dyrektora ochrony środowiska w Krakowie z dnia 8 sierpnia 2014 r. w sprawie ustanowienia planu zadań ochronnych dla obszaru Natura 2000 Puszcza Niepołomicka PLB120002 (Dz. U. Woj. Małopolskiego z 2014 r. poz. 4390).

\section{SUMMARY}

The occurrence of the Middle Spotted Woodpecker depends primarily on the presence of trees with very cracked bark. Oaks, even when young, have bark more deeply cracked than in other tree species. The aim of this study was to determine the relationship between the characteristics of trees and stands of different species composition (coniferous and oak-hornbeam forest) and the presence/breeding of the Middle Spotted Woodpecker. In this work we found no significant differences between probable breeding and breeding sites of the Middle Spotted Woodpecker in terms of the following stand characteristics: total number of dead branches, number of sporophores on stems, basal area of dead trees, maximum diameter at breast height and basal area of oak (Fig. 1). However, oak stands were found to be older at breeding sites (Fig. 2). Analysis of the preferences of the Middle Spotted Woodpecker at breeding sites suggests that this species requires an oak stand exhibiting diverse structure for the whole set of features. Stand age seems to be one of the most important features that the Middle Spotted Woodpecker uses when choosing its territory. With the age of the stand, the structure of the other features increases in variety and diversity (necroses, sporophores, dead branches, etc.).

Wptynęto: 30.01 .2020 r.; przyjęto do druku: 01.04.2020 r. 